\title{
On the Development of the Cystocarp in Rhodomelaceae (II).
}

\author{
BY \\ REGINALD W. PHILLIPS, M.A., B.Sc., \\ Professor of Botany in the University College of North Wales, Bangor.
}

With Plates XII and XIII.

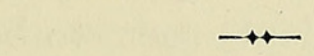

$\mathrm{T}$ an earlier number of the Annals of Botany (1), I gave $I$ an account of some observations on the development of the cystocarp in certain Rhodomelaceae of the genera Rhodomela and Polysiphonia. The results of these investigations showed that in the four species then under consideration there was a remarkable uniformity in the intimate structure of the procarp at the moment of the fertilization of the trichogyne; but that when spore-formation had set in, there was a varying degree of retrogressive absorption by the sporogenous cell of the cells from which it had been derived. The real nature of the sporogenous cell-whether it constituted in itself the auxiliary cell, as Schmitz averred, or was derived from the auxiliary (pericentral) cell-was left undetermined pending the direct observation of the conjugation of the carpogonium with an auxiliary cell.

The genera Rhodomela and Polysiphonia represent, however, only two of several groups of genera into which the family of the Rhodomelaceae has been subdivided. Agardh (2) divides

[Annals of Botany, Vol. X. No. XXXVIII. June, I896.] 
thirty-nine genera into eleven groups; Schmitz (3), forty-one genera into seven groups. I have therefore been desirous of extending my observations to others of these groups, for the purpose of ascertaining what variations, if any, in the structure of the cystocarp occurred within the limits of this exceptionally large family.

I have not found it possible to successfully make out the structure of the procarp from herbarium-material, and my investigations have therefore been limited to those genera which are represented in the flora of the coasts of North Wales, and of which I could collect material for myself.

The group Laurencieae, Schmitz, is represented in this district by three species of the genus Laurencia, Lamx., viz. L. pinnatifida, Lamx., L. hybrida, Lenor., and L. obtusa, Lamx. After some delay I have collected procarp-bearing material of the first-named species. Considering the abundance of the plant along the coast, the female plants seem to be very infrequent. The male plants are more common, but the great majority of the plants consist of individuals bearing tetraspores. Of the other species I have not yet been able to find female plants at all. To the apparent non-occurrence of cystocarp-bearing plants of L. obtusa, Harvey (4) has already directed attention. I have examined the procarps of $L$. pinnatifida with the greater interest, because the genus Laurencia is altogether excluded from the Rhodomelaceae by Agardh, and retained in the family Chondrieae (5), from which he had, however, already removed the genus Chondria itself under the name Chondriopsis. Schmitz has divided the family Chondrieae $\mathrm{Ag}$. into two groups of genera, one of which, including the genus Laurencia, is transferred to the Rhodomelaceae, the other group constituting the family Bonnemaisoniaceae.

The group Dasyeae is also represented in the district by at least three species of Dasya, viz. D. coccinea, C. Ag., D. arbuscula, C. Ag.; and D. ocellata, Harv. Dasya coccinea is common, and bears abundant cystocarps. To the examination of this species I have given considerable attention, and I propose to describe the development of its cystocarp in some detail. 
Chondria tenuissima, C. Ag., of Schmitz's group Polysiphonieae, is also of common occurrence in the district. In this plant Schmitz had already observed a considerable divergence in the structure of the procarp. In the absence of any figures illustrating his observations, I have thought it desirable to repeat, and if possible extend, the investigation, and particularly to figure the aberrant conditions.

\section{Dasya coccinea, C. Ag.}

The development of the cystocarp in this plant has already been the subject of a careful investigation by Janczewski (6), and his description is illustrated by no fewer than fifteen figures. As my own observations differ from those of Janczewski in some important particulars, it will be more convenient to deal with these points of divergence together. Schmitz does not appear to have examined Dasya at the time of publication of his paper on the fertilization of the Florideae ( 7$)$, at any rate there is no reference to the genus within the limits of the paper. Later $(3 a)$ he seems to have examined $D$. elegans, C. Ag., as that species is given as the type-species of the genus in his systematic review of the Florideae. Later still (8) he made a careful survey of the genus for taxonomic purposes, but this work does not include any description of the structure of the procarp. The genus has not been figured in the publications of Bornet and Thuret.

Dasya differs sharply from most other Rhodomelaceae in the fact that its axis is, as was shown long ago by Kny (9), a sympodium. The allied genus Heterosiphonia, Mont., recently re-established by Agardh (10) and Schmitz (8a), alone seems to share with Dasya this peculiarity. It might fairly be expected that so profound a difference of structure as that between plants with monopodial and sympodial axes would be accompanied by other differences, possibly in the structure of the procarp.

The procarps of Dasya coccinea arise in great numbers close up to the growing apex of the plant. They are usually borne on the fourth joint from the sympodial axis. In these cases 
the second joint from the axis gives rise to a branch, which shares in the formation of a secondary sympodial axis of limited growth. Janczewski has observed that occasionally the procarp appears on the second joint itself. The occurrence of a procarp does not, however, prevent the axis branching at that joint (Figs. I, 2, 3), and the younger branch may even fork once again (Fig. 3). The exhaustion of the axis occasioned by the formation of a procarp seems to set a limit to any considerable development of a sympodium beyond the procarp. It is therefore usual to find only three filaments, each consisting of about a score of cells, which persist until the maturation of the cystocarp. This is the so-called 'involucre' of the species. By some authors the cystocarp is spoken of as 'calcarated.' In other Rhodomelaceae I have invariably found that the procarp is borne upon the second joint of a lateral appendage, now usually called a leaf. The thallus of Dasya possesses no such lateral appendages, and the procarps, in common with other parts of the thallus, must be regarded as axial structures. Their occurrence upon a second or fourth joint of a seeming branch has thus no significance in the comparative morphology of the family. Kny found that the branches arise at times upon the third or fifth joint, and it is probable that the procarp will also be found in those situations. The persistence of the filaments in Dasya beyond the procarp must, no doubt, be correlated with the fact of its sympodial growth. The leaves of most Rhodomelaceae are fugitive structures, disappearing a short distance behind the growing apex, and when, in these cases, the procarp-bearing leaf withers away beyond the third joint, it may be regarded as exhibiting the same fugitive character.

A common occurrence in Dasya coccinea is the relapse of a procarp into an ordinary corticated joint when no spermatium reaches the trichogyne. Only a small proportion of the procarps formed at the apex mature into cystocarps, and every stage of retrogressive transformation may be observed. This is clearly a different process from that which 
commonly occurs in Rhodomela subfusca, where the unfertilized procarps become transformed into axes of limited growth. It has occurred to me that as branches in various Rhodomelaceae are borne upon the persistent basal cells of the leaves (9), the same process may occur in Rhodomela, and the metamorphosis into a branch of a procarp that has remained unfertilized, may be due to the sprouting of the lowest joint.

The procarps of Dasya are much more compact and opaque than those of other plants of the family which I have examined. The cell-wall does not swell equally under treatment with glycerine, and I have found the examination of the procarps in an entire condition very tedious and troublesome. Latterly I have adopted the practice of passing material preserved in formaldehyde into a weak solution of gum-arabic, and making sections with the aid of a freezing microtome. For the study of the later stages in the development, when it becomes still more opaque, some method of section-cutting becomes absolutely necessary. Sections cut in frozen gum may afterwards be washed free from the gum, stained in Hoffmann's blue or some other suitable stain, and mounted for examination in strong glycerine. Sections obtained by cutting in paraffin offer no advantages for the purposes here in contemplation, viz. the tracing of the genetic relationship of the contents of the cystocarp. Provided that the sections are not opaque, the thicker they are, the better for the purpose of the investigation. When, however, other problems come to be solved, such as the structure and behaviour of the nucleus in the cells concerned in reproduction, section in paraffin, to which the material readily lends itself, will be found the only available method. The figures of Dasya, however, accompanying this paper have been obtained from material fixed in formaldehyde, cut in frozen gum, stained in Hoffmann's blue, and mounted in strong glycerine.

The central cell of the joint which bears the procarps gives off five pericentral cells, and it is the fifth, occupying the median position above (towards the sympodial axis), which gives rise to the essential structures of the procarp. It is 
noticeable that whatever be the number of 'siphons' in Rhodomelaceae, whether four as in Polysiphonia violacea, or more than twenty as in Polysiphonia nigrescens, the number of pericentral cells cut off at the procarpial joint is always five. Dasya coccinea has about nine pericentral cells, besides a considerable additional cortex ; the central cell cuts off five pericentral cells. The carpogonial branch is four-celled as elsewhere, the terminal cell-the carpogonium-emerging at first as a minute papilla, and afterwards as a greatly elongated trichogyne. The trichogyne is unusually long, because it has to extend far enough to clear the tufts of filaments which terminate the fertile axes. Of the cells of the carpogonial branch, the lowest and the highest (the carpogonium) are in Dasya much larger than the two intermediate cells, and none of the four can be so sharply differentiated by staining as is the case in Rhodomela and Polysiphonia at the corresponding stage.

I have looked carefully into the young procarps for those sterile derivatives of the pericentral cell which are invariably present in the other species, but I am not sure that both of these branches are present, or that even one is always present, at the stage when the carpogonial branch is already fully formed. Occasionally a single inferior cell may be detected (Fig. I). Both branches may, however, be found a little later: the other pericentral cells have at this stage formed a complete investment for the fifth cell and its derivatives; the procarp never assumes the 'bi-valve' appearance, observable in Polysiphonia and elsewhere. There is merely a slight hemispherical swelling on the upper side of the branch, from a pit in which the trichogyne emerges.

Those procarps which advance beyond this stage are relatively few in number, and though the cystocarps appear numerous when mature and visible to the naked eye, the search for them in the intermediate condition just before they become thus visible is wearisome. When the procarp of this stage is examined, it will be found that an internal cavity is forming, owing to the growth of luxuriantly-branched 
filaments derived from the pericentral cell. These filaments consist of cells whose walls are thick and transparent, so that the core appears as a mass of dense mucilage in which the tufts of cells are imbedded. At the same time a pair of cells derived from the pericentral cell gives rise to numerous rows which radiate so as to line the entire cavity, converging to the pore. These are the paranematal filaments of other Rhodomelaceae; but they are here formed relatively much earlier in the development of the cystocarp, and play a greater part in the formation of the wall.

When the core of filaments already referred to are examined more closely, they are found to originate, as I have said, in the pericentral cell, and that at two points only. One tuft arises in the inferior position, and branches freely; the other in a lateral position, slightly more luxuriantly branched. Judging from the distance of the cystocarp at this stage behind the growing apex, where the young procarps protrude their trichogynes, an interval of many days (possibly weeks) must have elapsed after the fertilization of the trichogynes before this stage is reached. I was therefore of opinion that these tufts must be sporogenous filaments in a rudimentary condition, particularly as no other structures were apparent which could be regarded as rudiments of carpospores. However, after examining many cystocarps in this condition, two considerations induced me to change this view. First, these filaments arose, as already mentioned, as two branches, one in the inferior position and one in a lateral position. In all other Rhodomelaceae two sterile branches arise in these situations before the fertilization of the trichogyne. In most Rhodomelaceae these consist, one of one cell, another of two cells, and even after fertilization their future development is limited to the production of three new cells, one from each of the three original cells. In Chondria temiissima these branches exist already at the period of fertilization of the trichogyne, as Schmitz has shown, as two tufts of branches of considerable size. The question arose whether the two branches of Dasya, which arose almost entirely after fertilization of 
the trichogyne, were not the equivalents of these, and not 'carpogenous,' but sterile in their nature. The second circumstance which aroused my suspicion was the fact that in cystocarps at this stage I repeatedly found the carpogonial branch lying intact near the base of these filaments. In other Rhodomelaceae the carpogonium itself, soon after fertilization, becomes disorganized, and cannot be traced; the three remaining cells of the branch atrophy, and are in some cases detached and pushed off on the subsequent formation of spores. Might not the formation of the sterile branches in Dasya be delayed, taking place almost wholly after the fertilization of the trichogyne; and might not the fertilized carpogonium remain quiescent pending their formation, and until a suitable stage had been reached for conjugation with an auxiliary cell? Later observations gave a complete answer to these inquiries.

There is no doubt that we have here an analogy with the cases of those Orchidaceae which only form ovules upon the placenta, after pollen has been deposited upon the stigma, the pollen-tube delaying its advent to the ovary until the ovules have been formed. So here, the procarp only proceeds to the further development of the pericarp, and the formation of the 'placental apparatus' including the auxiliary cell, when a spermatium reaches the trichogyne, the activity of the fertilized carpogonium remaining in abeyance until the completion of these operations. Some of the sections illustrating this stage showed that a superior cell was cut off from the pericentral cell, as was found to be the case in most other Rhodomelaceae.

Fig. 4 shows an exceedingly interesting stage in the development of the cystocarp. The two sterile tufts have branched copiously, only a portion of the ultimate filaments being shown in the figure. The paranematal filaments have almost reached the carpostomium. The superior cell has been cut off from the pericentral cell, and at the base of the lateral branch lie the cells of the carpogonial branch. As every pit-connexion in this figure was made out clearly, there is no doubt as to the identity of the cells. A stout process 
is, moreover, represented as stretching across between the carpogonium and the superior cell cut off from the pericentral cell. This, I have no doubt, represents the conjugation of the carpogonium and an auxiliary cell, which, though it was inferred that it occurred in Rhodomelaceae, had not previously been observed in any species in the family. The fertilization of an auxiliary cell by the carpogonium has been directly observed in Dudresnaya, Polyides, Gloeosiphonia, and other genera representing different families of the class Cryptoneminae. Schmitz also in his later researches (11) observed this fusion in the Ceramiaceae among the families of the class Rhodomeninae. I have myself during the last summer seen the conjugation-process in Antithamnion plumula, Thur.; but I had hitherto failed to observe it in the Rhodomelaceae. The figure is a faithful drawing, by means of a camera lucida, of the appearance presented. A thick short process is seen extending between the carpogonium and the auxiliary cell. In the section it was deeply stained by the Hoffmann's blue, and in this respect, as well as in the general appearance, corresponded closely with the conjugation-process which I had previously seen in Antithamnion plumula. The preparation, however, left much to be desired. While the continuity of the process with the auxiliary cell was clear, it was directed obliquely against the carpogonium so as to prevent the continuity with that cell being equally clearly traced. I regret that, in spite of many attempts, I have not been able to repeat this observation in other sections. Once, indeed, in the same situation I found a process, which I have no doubt was the remains of the copulation-tube. In the Ceramiaceae, Schmitz found that a small corner of the carpogonium was cut off, which fused with the auxiliary cell by means of a short tube. Whether anything corresponding to this occurs in Dasya could not be determined in the preparation. The observation leaves no doubt, however, that in Dasya, at any rate, the cell which plays the rôle of the auxiliary cell, is the one which I had previously called the sporogenous cell. The pericentral cell is not here the auxiliary cell. And I have little doubt now 


\section{I94 Phillips.-On the Development of the}

that this is the rule in the Rhodomelaceae whenever a superior cell is cut off at all. The considerable delay before the conjugation with the auxiliary cell, which takes place in Dasya, may indicate some amount of delay in other cases, and my former contention, that the superior cell was not usually cut off until after fertilization of the trichogyne, has less weight as an objection to its being considered an auxiliary in these cases also.

The next figure (Fig. 5) represents the cystocarp one step further in development. The carpogonial branch is still traceable, but now the auxiliary cell has begun to form sporogenous filaments, represented by a dense group of cells seated upon the auxiliary cell. Fig. 6 shows one of these sporogenous filaments (shorn of lateral branches) which has now so developed as to outstrip the tufts of sterile filaments. The cells of these fertile filaments multiply doubtless with great rapidity. The protoplasm is densely granular, the nucieus deeply stained, and the pit-connexions are large and conspicuous. It is characteristic of the cells of these filaments that they present a concave surface upwards, into the well of which the pit-connexion is made. The cells of the sterile filaments are, on the other hand, separated from one another by a dense mucilage, and their pit-connexions are attenuated. No absorption by the auxiliary cell of the pericentral and other cells takes place in Dasya, as so often happens elsewhere. The sterile cells may be observed, though in an atrophied condition, even after the carpospores are already recognizable. Though absorption does not take place, there is no doubt that a large number of cells surrounding the central cell are put into requisition to supply the material for the abundant formation of carpospores, which follows upon the fertilization of the auxiliary cell. Among these are the cells of the paranematal filaments. These cells and those below the central cell stain deeply, and seem to be charged with reserve material just before the formation of spores; afterwards they become vacuolated and stain feebly.

The carpospores are ellipsoidal, and are formed in chains 
of three or four at the distal ends of the gonimoblast filaments. In other Rhodomelaceae not more than one or two cells usually intervene between the placenta (i.e. the auxiliary cell and its absorbed neighbours) and the carpospore. In some cases the carpospore would seem to be sessile upon the placenta. In Dasya, however, long filaments, sometimes pinnately, sometimes subdichotomously branched, interpose eight or ten cells between the placenta and the nearest spore. This stage of the cystocarp is represented in Fig. 7 .

This account of the development of the cystocarp in Dasya coccinea will be found to differ considerably from that given by Janczewski among a series of observations on the sexual reproduction of Florideae (6). This author found the procarp to contain, as derivatives of the pericentral cell, a 'trichophoric apparatus' of four cells, and two contiguous 'carpogenous' cells. These 'carpogenous' cells are no doubt the rudiments * of the sterile branches. In procarps which are left unfertilized Janczewski found, however, that these cells divide to form a 'carpogenic system' of short filaments directed towards the exterior, and constituting the convex portion of the procarp. I am at a loss to account for this statement, as I have found that in unfertilized procarps the earlier convexity is soon lost. Doubtless the cells of the sterile filaments do not die, as, according to Janczewski, do the cells of the 'trichophore.' I have not, however, detected anything in unfertilized procarps corresponding to this description. The writer remarks that the limits of the 'carpogenous system' are not well defined. Further, in fertilized procarps the 'carpogenous' tissue is said to be more vigorous at first, but soon to pass into a condition of rest, during which the vegetative force is exclusively employed in the formation of the pericarp. The pericarp is derived from the two lateral pericentral cells, assisted by neighbouring tissue. This supplementary tissue is, as I have shown, an internal system of paranematal filaments. After the pericarp has attained its definitive aspect, the 'carpogenous system' is described as awaking from its sleep, and producing, at the expense of its terminal cells, the sporogenous filaments, 
As I have shown, this is a misunderstanding of the nature of these filaments; the term 'carpogenous system' is a misnomer as applied to them, for they are sterile, and the real sporogenous filaments arise later, not from their terminal cells, but below from the auxiliary cell. The period of rest which Janczewski found to exist may, however, admit of explanation. I have frequently observed cystocarps of the outward shape of mature cystocarps, but with only the tufts of sterile filaments occupying a small space at the base of the cavity. It has occurred to me that these are cystocarps in which the conjugation of the carpogonium with the auxiliary cell has either failed to take place or been greatly delayed. Otherwise the repose is nothing more than the cessation in the growth of the sterile filaments. The function of these sterile branches is partly nutritive perhaps, but they probably also serve the purpose of opening out a cavity for the cystocarp in the dense tissue, by means of their mucilaginous cell-walls. They have, * however, with a varying degree of development, a remarkable morphological constancy in all the Rhodomelaceae which I have examined.

Askenasy (12) seems more recently to have described the development of the cystocarp in Dasya Berkeleyi (Mont.), J. Ag., and found that the phenomena were similar to what occurred in Polysiphonia. Dasya Berkeleyi has, however, latterly been removed by Agardh (10 b) from Dasya to the genus Heterosiphonia, Mont. This course is also followed by Schmitz $(8 a)$. But while the plant might therefore be expected to depart somewhat from the normal type of Dasya, still, inasmuch as it presents the character of a sympodial growth like Dasya, it might be expected in the structure of its cystocarp to show affinities to Dasya rather than to Polysiphonia. Apparently this is not the case. I regret I have not been able to consult Askenasy's paper directly.

In the same work (10) by Agardh as that in the course of which he has re-established the genus Heterosiphonia, Mont., he has generally revised the genus Dasya, and discussed the structure of the 'nucleus,' in the genus as reconstituted. He refers to. 
the difference in the appearance of the 'nucleus' when it is less evolved, and consists of shorter, slightly-branched filaments, from that of the more fully-developed 'nucleus' with greatly-prolonged and much-branched filaments. This difference, I do not doubt, is the difference between the cystocarp when it contains only tufts of sterile filaments, and when it contains the larger system of sporiferous filaments. Writing of Dasya coccinea itself $(10 a)$, he says: 'In Dasya coccinea cuius nucleum fasciculo basali simpliciore constitutum observavi, iam dignoscere licet plures ramos inferne firmiores, quos sensim magis evolutos fieri facilius assumeres.' These 'rami firmiores' are almost certainly the sterile earlier contents of the cystocarp, and, as my figures show, they do not gradually develop into the sporiferous threads.

\section{Chondria tenuissima, C. Ag.}

Here, as in Rhodomela and Polysiphonia, I find the procarp is formed upon one of the so-called leaves, and upon the second joint from the axis. Considering that the axis is relatively stout and strongly corticated, it might seem unlikely that only one stalk-cell intervened between the procarp and the axis. This is, however, the case (Fig. 8), as the cell becomes greatly elongated and attenuated. Janczewski's figures $(6 a)$ of this plant err in showing more than one axial cell in the pedicel. Bornet and Thuret's figure (13), however, makes the point clear.

At the time of the fertilization of the trichogyne, the two sterile branches have already attained much the same degree of development as that which they reach long after this stage in Dasya. The paranemata have not yet arisen from the central cell, and the four-celled carpogonial branch lies in a lateral position, pushed on one side by the luxuriant growth of the lateral sterile branch. After fertilization the sterile filaments cease to grow almost entirely. The paranemata, however, grow apace, and the upper portion of the cystocarp is formed almost wholly by means of these rows of cells. The 


\section{I98 Phillips.-On the Development of the}

limiting line between the cortex derived from the pericentral cells, and the tissue emerging as paranematal filaments, may be detected at this stage upon the external surface. The carpogonial branch does not immediately atrophy, but remains for some time at the base of the sterile branches. I have failed to observe in this plant the separation of a superior cell from the pericentral cell, or a process of conjugation of the carpogonium with the pericentral cell. A later condition, when an additional (third) branch may be seen to have arisen from the pericentral cell, can be distinguished. This is certainly the gonimoblast-filament arising after conjugation with an auxiliary cell, which in this case may have been the pericentral cell. Schmitz also failed to find in this plant the separation of a distinct auxiliary cell. After the appearance of the gonimoblast-filament there now begins, as Schmitz has pointed out, a process of absorption, starting from the pericentral cell, which attains remarkable dimensions. First, the proximal cells of the sterile branches become continuous with the pericentral cell by the enlargement of the pits and the disappearance of the refractive plates which usually close them. This process does not, however, reach the distal cells at all ; and indeed the inferior branch may be seen well defined, though attenuated, at a late stage of spore-formation. In this it resembles the condition of both branches in Dasy . The absorption extends from the pericentral cell backwards to the central, and thence to the proximal cells of the paranematal filaments (Fig. IO). By the confluence of these cells there is formed the large, amorphous, multinucleate mass of protoplasm, to which the term 'nucleus' has been more particularly applied by earlier writers. From this mass the pyriform carpospores arise either directly or by the intervention of short gonimoblast-filaments. In no case do carpospores arise from the sterile filaments, or even from their proximal cells which fuse with the 'nucleus,' as long as they are distinguishable from the rest of the protoplasmic mass. 


\section{LAURENCIA PINNATIFIDA, Lamx.}

The genus Laurencia is, as I have stated earlier, placed by Agardh (5) outside the Rhodomelaceae in the family Chondrieae. Schmitz (3) has included it among the Rhodomelaceae, but placed it in a tribe Laurencieae, distinct from the Polysiphonieae, which is made to include Chondria. Chondria tenuissima, C. Ag., is however Laurencia temiissima, Grev., of the Algae Britannicae (14) and the Phycologia Britannica (4a). I was therefore curious to see what light would be thrown upon the relative position of Chondria and Laurencia by the comparison of the development of the cystocarp, and I have found that the two plants, C. tenuissima and L. pinnatifida, exhibit the closest correspondence in the essential elements of the cystocarps. In Laurencia the procarps are borne upon the 'leaves' which crowd the depression at the apex of growth; the second joint of these leaves is the one which furnishes the essential procarpial structures; the carpogonial branch is four-celled; two richly-branched tufts of sterile filaments exist already at the moment of fertilization of the trichogyne; as far as I could make out, the gonimoblastfilaments arise here also directly from the pericentral cell, which in that case acts as the auxiliary cell; and the same absorption of neighbouring cells takes place here as in Chondria. The paranematal filaments are, however, still more luxuriant in Laurencia than in Chondria, and line the cavity four or five cells deep. The wall itself also consists of many more layers than is the case in Chondria. Chondria temissima is an annual plant, and has a thin 'cortex' compared with Laurencia pinnatifida, which is a perennial, and has a 'cortex' so deep that its 'articulate' character is greatly obscured. Allowing for this difference of habit, the two plants would seem, judging from the structure of the cystocarp, to be very closely allied. It seems to be generally agreed that the cystocarp in Rhodomelaceae usually presents such uniformity that generic characters cannot be founded upon characters derived from it, and while the great similarity of Laurencia 
and Chondria may not now justify their inclusion in one genus, after the plan of earlier authors, it would certainly seem to be a reason for not separating them among different tribes as Schmitz does, much less among different families as Agardh does.

\section{Polysiphonia thuyoides, Harv.}

This plant belongs to the strongly corticated group of the genus Polysiphonia, and is the Rhytiphlaea thuyoides of the Phycologia Britannica $(4 b)$. I have found the procarps to correspond closely with those of other Polysiphonia, excepting that at the period of the fertilization of the trichogyne a superior cell, undoubtedly an auxiliary cell, is already separated from the pericentral cell. I have hitherto assumed that this separation of a superior cell was a consequence of fertilization of the trichogyne. It would, however, appear to be cut off in this case at, or even before, that period; usually it appears immediately after, and in Dasya long after, that period.

\section{SUMMARY.}

I propose now to briefly summarize the results obtained from the examination of the eight species of Rhodomelaceae, the cystocarps of which I have studied in some detail. The description of the cystocarps of four of these species is contained in a former paper in the Annals (1). The eight species represent five genera, and four of the groups of genera (or tribes) as arranged by Schmitz $(3 b)$.

Tribe Rhodomeleae

" Laurencieae

"Polysiphonieae

,, Dasyeae
Rhodomela subfusca.

Laurencia pinnatifida.

Polysiphonia nigrescens, fastigiata, violacea, and thuyoides.

Chondria temuissima.

Dasya coccinea.

In entering upon a comparison it will be found convenient to take the structures in the following order: the procarp in 
general ; carpogonial branch ; sterile branches ; auxiliary cell ; paranematal filaments; and the pericarp.

Procarp.-A modified leaf in all cases (except Dasya), the second joint of which is the fertile joint. In Dasya the procarp is axial.

Carpogonial branch.-Invariably four-celled, arising from the fifth pericentral cell, and curving so as to bring the carpogonium near to the cell from which it arises.

Sterile branches. - Two such branches arising from the pericentral cell-one in the inferior position, one in a lateral position-are invariably present.

In Rhodomela and Polysiphonia the inferior branch is onecelled, the lateral branch is two-celled at fertilization of the trichogyne, becoming respectively two-celled and four-celled later.

In Chondria and Laurencia both branches are luxuriantly branched into tufts of filaments at the time of fertilization, developing but little afterwards, and becoming partially absorbed on spore-formation.

In Dasya the two branches are represented but slightly, if at all, at the time of fertilization, but become richly branched afterwards, still before spore-formation sets in.

Auxiliary Cell.-In Rhodomela, Polysiphonia, and Dasya there is cut off from the pericentral cell, a superior cell which is the auxiliary cell and conjugates with the carpogonium. In $P$. thuyoides this cell is cut off before fertilization of the trichogyne, usually immediatelyafter, in Dasya long after.

In Chondria and Laurencia it would seem that the pericentral itself acts as the auxiliary cell.

Paranematal filaments. - These derivatives of the central cell are invariably present, and line the cavity of the cystocarp.

In Rhodomela and Polysiphonia they are few in number and widely separated.

In Chondria and Dasya they form a continuous layer, often more than one cell deep.

In Laurencia they are several cells deep, the inner then becoming more attenuated than the deeper seated. 
The Pericarp.-Formed chiefly from pericentral cells of the fertile joint, but the joints above and below sharing in its formation.

In Rhodomela and Polysiphonia the wall is one cell thick.

In Chondria and Dasya, several cells thick at the base, becoming thinner near the pore.

In Laurencia, many cells thick throughout.

The degree of development of the wall corresponds roughly with the degree of development of the so-called cortex of the vegetative parts.

\section{BIBLIOGRAPHY.}

1. On the Development of the Cystocarp in Rhodomelaceae; R. W. Phillips. Annals of Botany, Vol. ix, I895, pp. 289-305.

2. Analecta Algologica; J. G. Agardh. Lundae, I892, pp. I42, I 43.

3. Systematische Uebersicht der bisher bekannten Gattungen der Florideen; Fr. Schmitz, Flora, I889, Heft 5. Marburg. 3 a, p. 16. 3 b, pp. I $2-15$.

4. Phycologia Britannica; W. H. Harvey. London, 1849-5I, Pl. I48. 4 a, Pl. 198. 4 b, p. 87 .

5. Species, Genera, et Ordines Algarum; J. G. Agardh. Vol. iii, I, Epicrisis. Lundae, i 876 , p. 636 .

6. Notes sur le Développement du Cystocarpe dans les Floridées; Ed. de Janczewski, Mém. de la Soc. Nat. de Cherbourg. Tome X, pp. I29, I $33,1876.6$ a, Figs. 16 and $\mathrm{I} 7, \mathrm{Pl} .4$.

7. Untersuchungen über die Befruchtung der Florideen; Fr. Schmitz, Sitzungsber. der Berliner Akad. der Wissensch. Beılin, I883. English translation by W. S. Dallas, in Annals and Magazine of Nat. Hist. 1884.

8. Die Gattung Lophothalia, J. Ag.; Fr. Schmitz, Ber. der deutschen Bot. Gesellsch. Band XI, pp. $212,234,1893.8$ a, p. 226.

9. Ueber Axillarknospen bei Florideen; Kny, Festschr. Gesellsch. Naturfor. Freunde zu Berlin. 1873 .

10. Till Algernes Systematik VI ; J. G. Agardh ; Lund. Univ. Arsskr. Tom. XXVI, Lundae, I 89 ग. 10 a, p. 80 , note I.

11. Kleinere Beiträge zur Kenntniss der Florideen I; Fr. Schmitz; La Nuova Notarisia. Series III, I89I, p. II 7 .

12. Forschungsreise S. M. S. Gazelle: Th. IV. Botanik, Algen; E. Askenasy, Berlin, I888. Referat; Botanisches Centralblatt. Band XXXVII, p. II 2, I 889 .

13. Études phycologiques; Bornet et Thuret. P. 92, Pl. XVIII, Paris, I 878 .

14. Algae Britannicae; R. K. Greville. Edinburgh, 1830, p. 1 I 3. 


\title{
Cystocarp in Rhodomelaceae (II).
}

\section{EXPLANATION OF FIGURES IN PLATES XII AND XIII.}

\author{
Illustrating Professor Phillips' paper on the Development of the Cystocarp \\ in Rhodomelaceae (II).
}

Abbreviations : aux. c. auxiliary cell; c. c. central cell ; carp. carpogonium; $c p . s p$. carpospore; gon. bl. gonimoblast-filaments; in. st. br. inferior sterile branch; l. st. br. lateral sterile branch: peric. c. pericentral cell; pn. paranema; $t r$. trichogyne.

The material was fixed in formaldehyde, and, after staining in Hoffmann's blue, mounted in strong glycerine. The figures were sketched by means of the camera lucida. The cells shaded by means of oblique lines are those of the carpogonial branch; the red shading indicates cells of the sterile branches; the shading by means of dots indicates paranematal filaments.

\section{P1. XII. Figs. I-7. Dasya coccinea, C. Ag.}

Fig. I. Lateral view of a procarp. $\times 800$.

Fig. 2. Front view of a procarp. $\times 800$.

Fig. 3. Lateral view of an older procarp, showing its position with reference to the lateral sympodial axis of limited growth; $a p$. represents the still growing apex. The three filaments on the distal side of the procarp are the 'involucre.' The procarp is represented as cut medianly, and as yet contains only sterile filaments. $\times \mathrm{I} 50$.

Fig. 4. A procarp at much the same stage as that represented in Fig. 3, more highly magnified. The auxiliary cell has now been cut off, and is in conjugation with the carpogonium. The cavity of the procarp is as yet chiefly occupied by the sterile filaments. $\times 700$.

Fig. 5. A still later stage, when the fertilized auxiliary has begun to form sporiferous filaments. The carpogonial branch is still recognizable. $\times 300$.

Fig. 6. A later stage, when the sporiferous threads have developed carpospores at their distal ends. Only one such thread, stripped of lateral branches, is shown. The carpogonial branch is no longer traceable. The sterile branches have become much attenuated. $\times 800$.

Fig. 7. Median section through a mature cystocarp. The sterile branches can no longer be traced. $\times 75$.

Pl. XIII. Figs. 8-Io. Chondria tenuissima, C. Ag.

Fig. 8. Median view of a procarp at the time of fertilization of the trichogyne, showing the connexion with the axis, and the two sterile branches. $\times 200$.

Fig. 9. The same stage, showing the carpogonial branch, and the inferior sterile branch. $\times 300$. 


\section{Phillips.-Development of the Cystocarp.}

Fig. Io. A later stage, when the pericentral (auxiliary) cell has absorbed the proximal cells of the sterile branches, and is in process of fusion with the central cell and the paranematal filaments. $\times 700$.

Fig. II. a. Diagrammatic representation of the contents of the procarp in Rhodomela and Polysiphonia at the time of fertilization of the trichogyne.

$b$. Diagrammatic sketch of the contents of the procarp of Chondria and Laurencia at the time of fertilization of the trichogyne.

c. Diagrammatic representation of the contents of the procarp in Dasya when spore-formation has begun. 
Annals of Botany
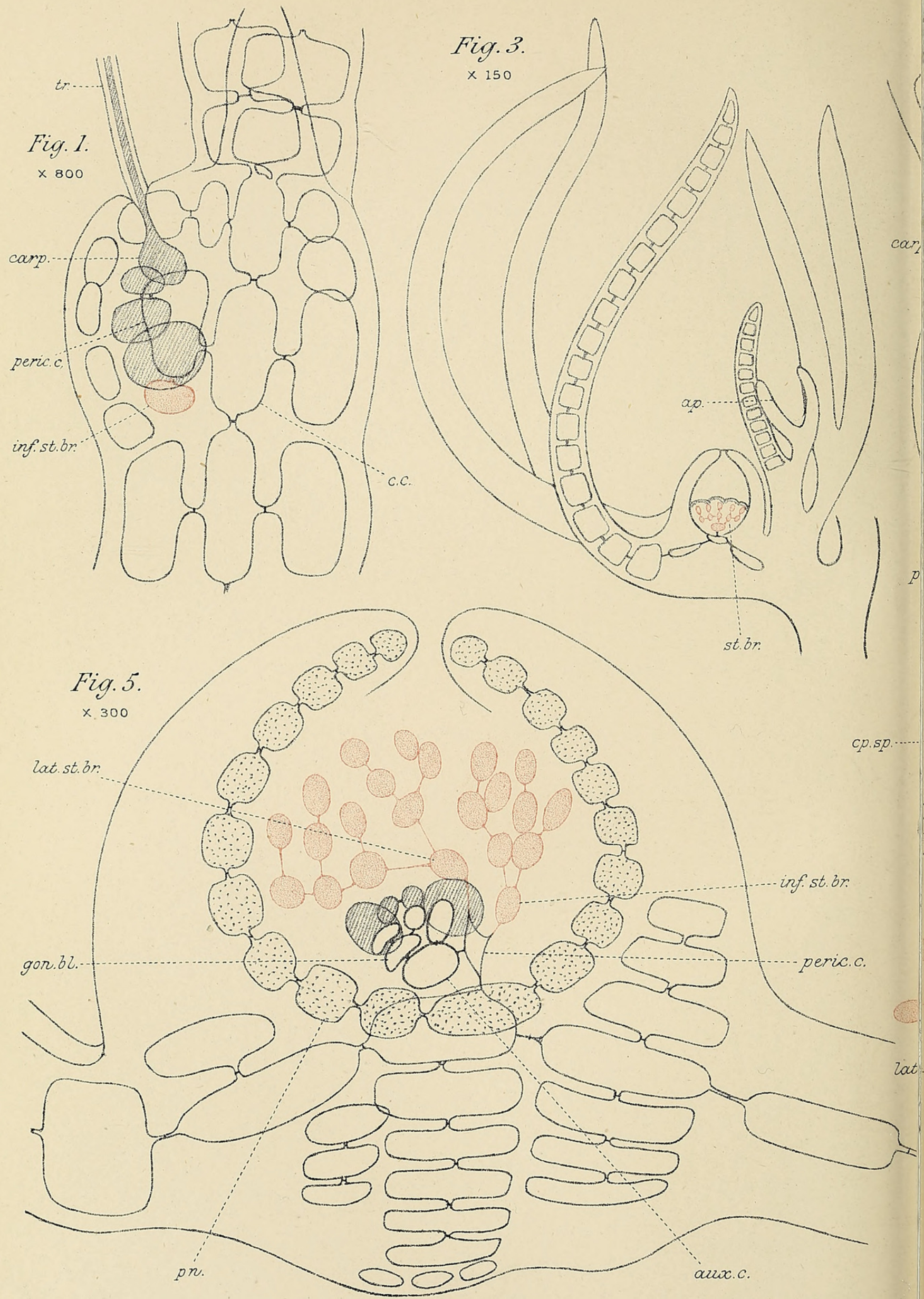

R.W.P. del.

PHILLIPS. - CYSTOCARP OF RHODOMELACEAE. 
VoL.X, PZ.XII.
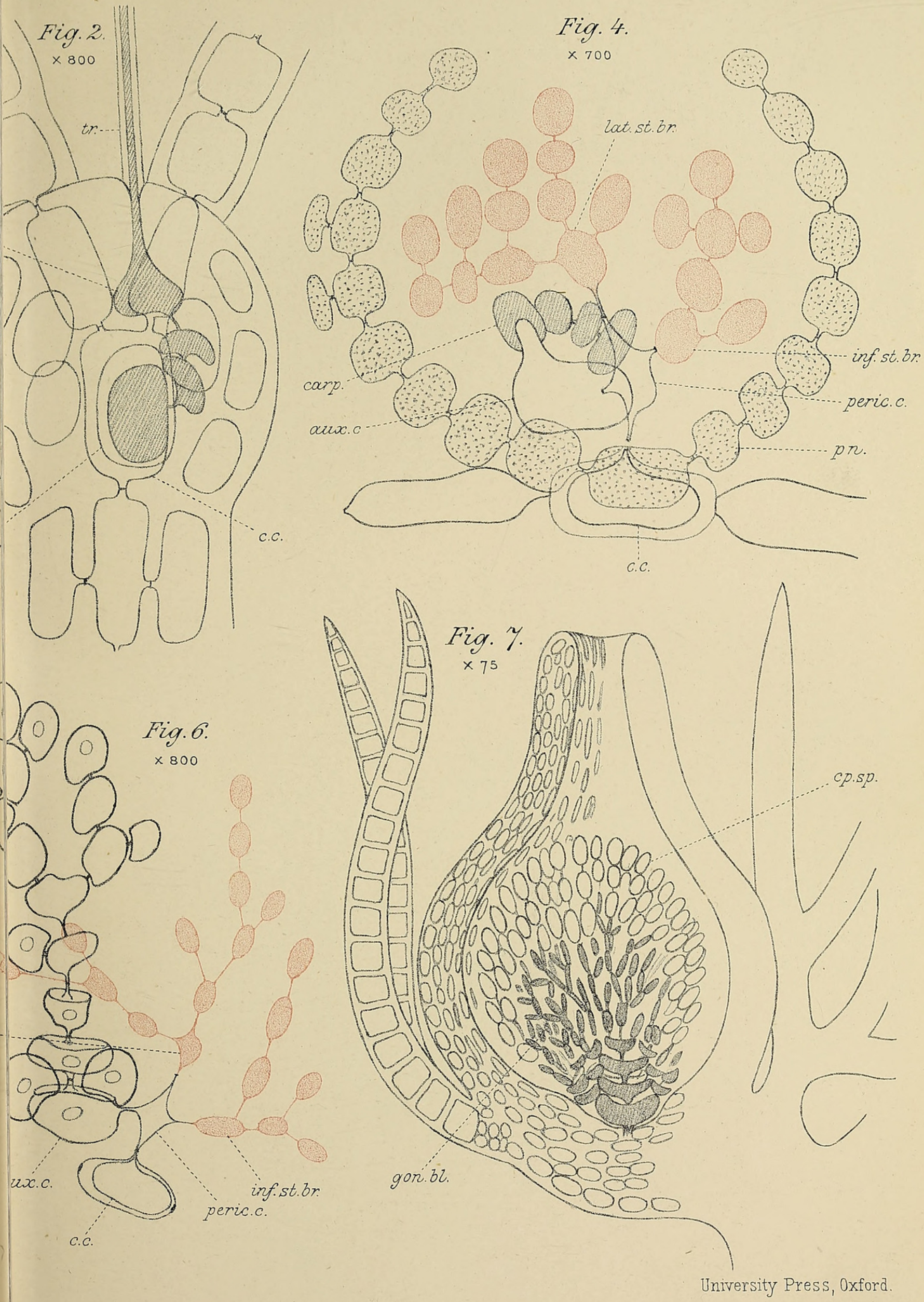


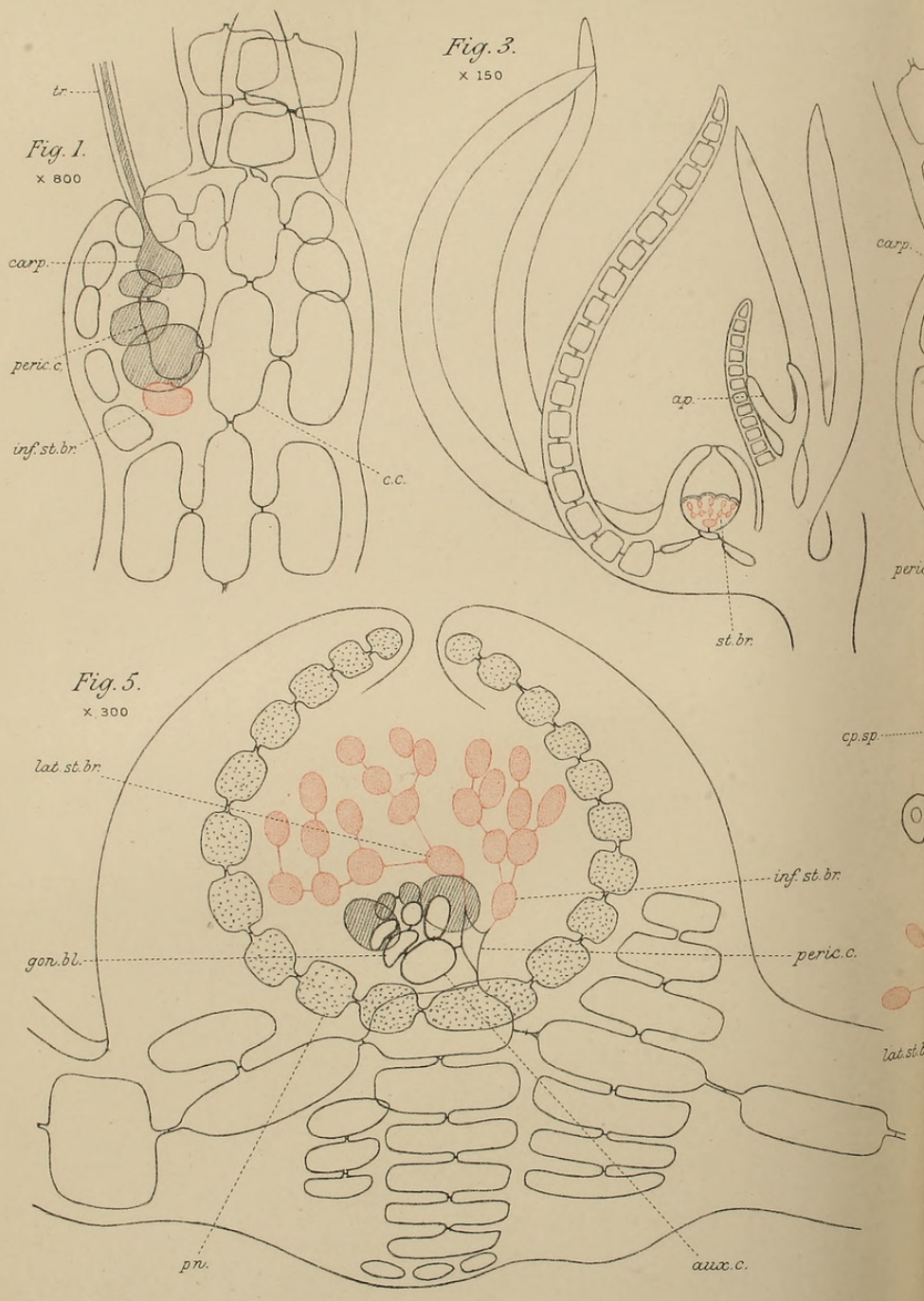

R.W. P. del.

\footnotetext{
PHILLIPS. - CYSTOCARP OF RHODOMELACEAE.
}
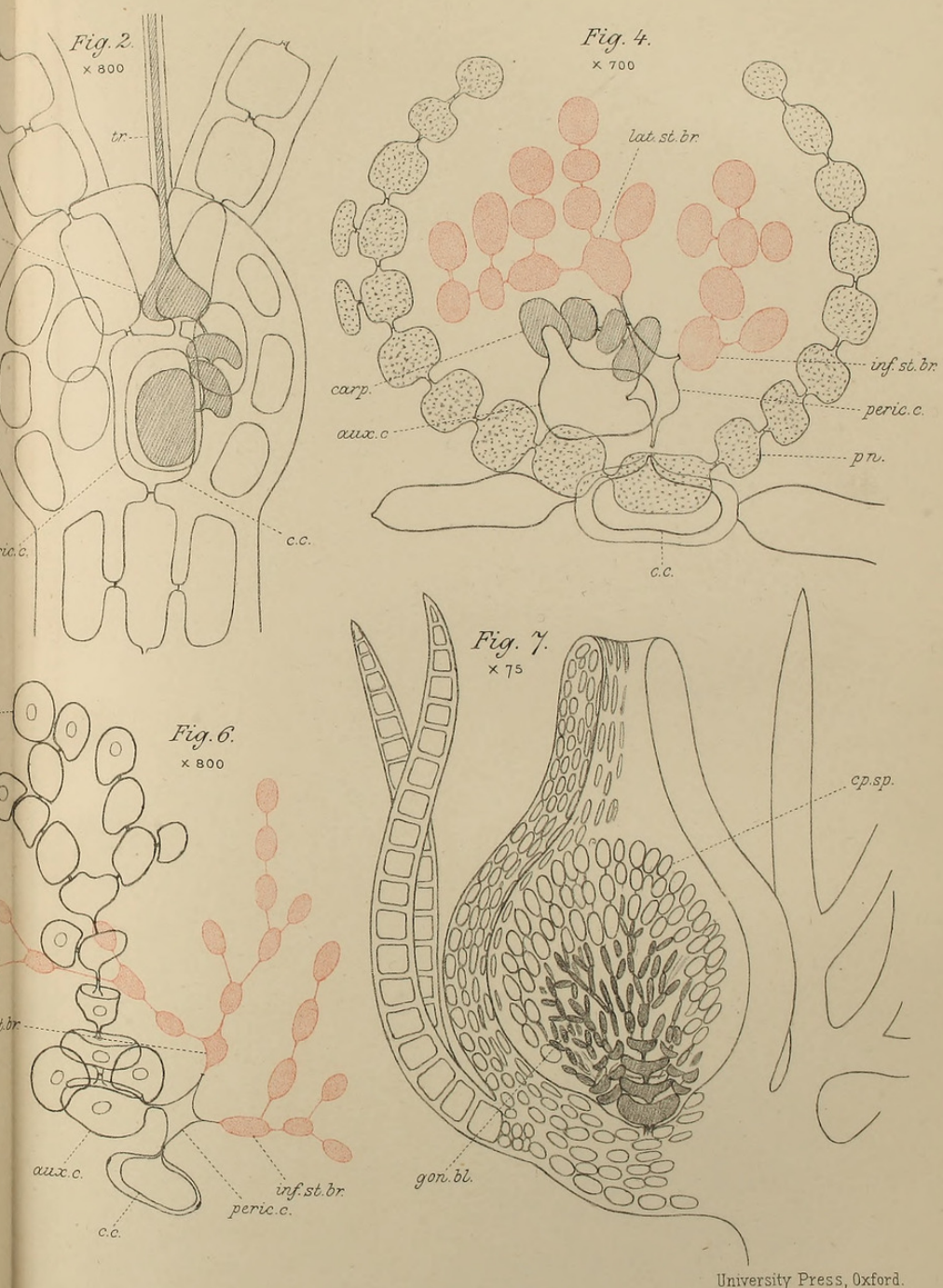


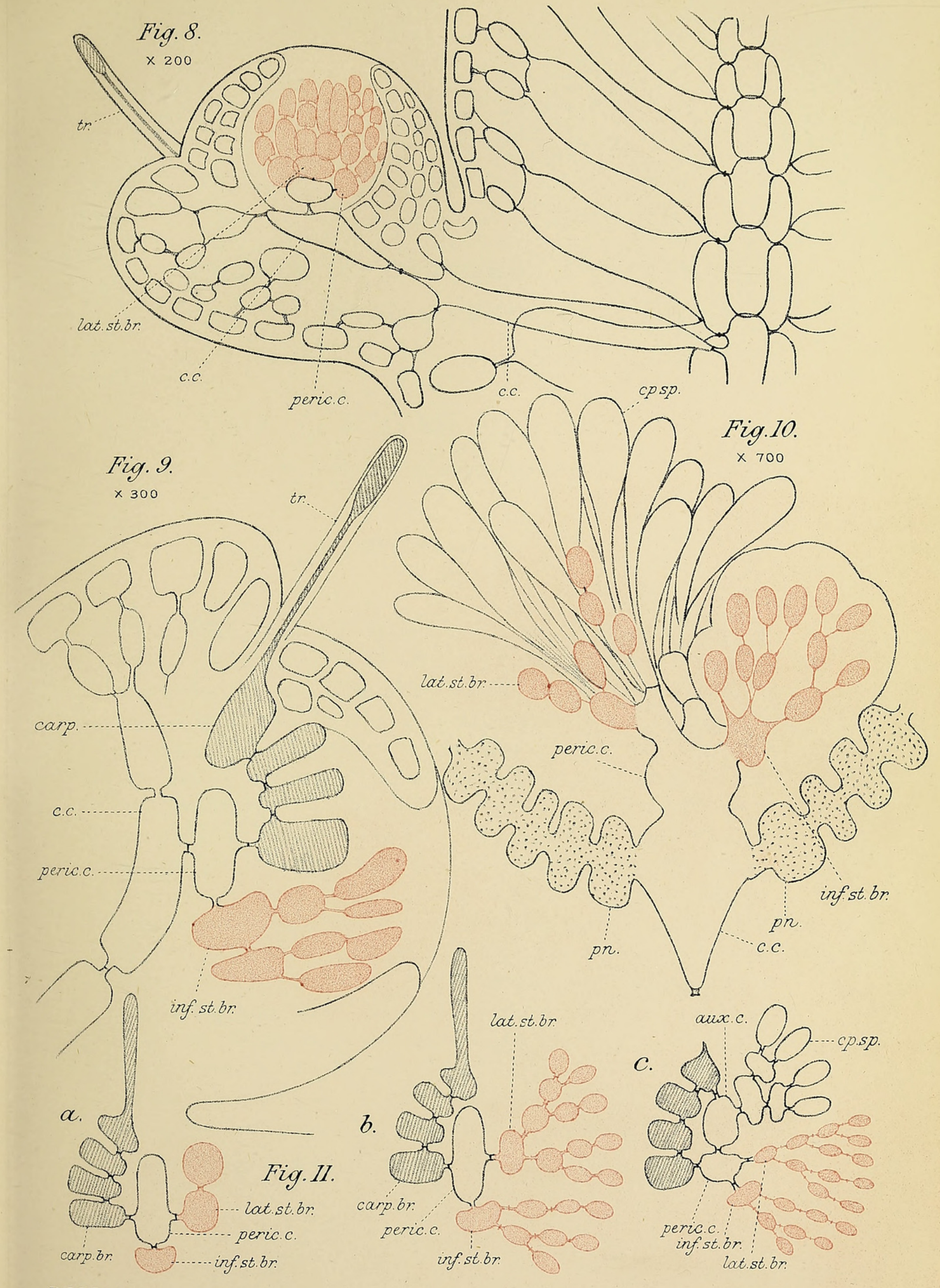

R.W.P. de\}.

University Press, 0xford. 


\section{$2 \mathrm{BHL}$ Biodiversity Heritage Library}

Phillips, Reginald W. 1896. "On the development of the cystocarp in Rhodomelaceae (II)." Annals of botany 10, 185-204.

https://doi.org/10.1093/oxfordjournals.aob.a088608.

View This Item Online: https://www.biodiversitylibrary.org/item/235772

DOI: https://doi.org/10.1093/oxfordjournals.aob.a088608

Permalink: https://www.biodiversitylibrary.org/partpdf/318420

\section{Holding Institution}

Smithsonian Libraries

\section{Sponsored by}

Biodiversity Heritage Library

\section{Copyright \& Reuse}

Copyright Status: Not in copyright. The BHL knows of no copyright restrictions on this item.

This document was created from content at the Biodiversity Heritage Library, the world's largest open access digital library for biodiversity literature and archives. Visit BHL at https://www.biodiversitylibrary.org. 